\title{
Protective Effects of Amburoside A, a Phenol Glucoside from Amburana cearensis, against $\mathrm{CCl}_{4}$-Induced Hepatotoxicity in Rats
}

Author
Affiliation
Key words
Amburoside A
Amburana cearensis
Fabaceae
hepatoprotective activity
carbon tetrachloride toxicity

received January 14, 2008 revised February 29, 2008 accepted March 4, 2008

\section{Bibliography}

DOI $10.1055 / \mathrm{s}-2008-1074501$

Planta Med 2008; 74: 497-502

(c) Georg Thieme Verlag KG

Stuttgart - New York

Published online April 10, 2008

ISSN 0032-0943

\section{Correspondence}

Dr. Luzia Kalyne A. M. Leal

Departamento de Farmácia

Universidade Federal do Ceará

Rua Capitão Francisco Pedro

1210

Fortaleza 60430-270

Brasil

Tel.: +55-85-3366-8279

Fax: +55-85-3366-8257

kalyne@ufc.br
Luzia K. A. M. Leal', Francisco Noé Fonseca ${ }^{1}$, Fábio Azevedo Pereira ${ }^{2}$, Kirley M. Canuto ${ }^{3}$, Cícero F. B. Felipe ${ }^{2}$, Juvênia Bezerra Fontenele ${ }^{2}$, Márcia V. Pitombeira ${ }^{4}$, Edilberto R. Silveira ${ }^{3}$, Glauce S. B. Viana ${ }^{2}$

1 Departmento de Farmácia, Universidade Federal do Ceará, Fortaleza, Brasil

2 Departamento de Fisiologia e Farmacologia, Universidade Federal do Ceará, Fortaleza, Brasil

3 Departmento de Química Orgânica e Inorgânica, Universidade Federal do Ceará, Campus do Pici, Fortaleza, Brasil

4 Departamento de Patologia, Universidade Federal do Ceará, Fortaleza, Brasil.

\begin{abstract}
$\boldsymbol{\nabla}$

The aim of this study was to investigate the possible beneficial effects of amburoside A, AMB [4(O- $\beta$-D-glycopyranosyl)benzyl protocatechoate], against carbon tetrachloride $\left(\mathrm{CCl}_{4}\right)$ toxicity in rats. AMB is a phenol glucoside from the Brazilian medicinal plant Amburana cearensis, popularly used for the treatment of respiratory tract affections. Acute AMB ( 25 and $50 \mathrm{mg} / \mathrm{kg}$, i.p. or p.o.) treatments of $\mathrm{CCl}_{4}$-intoxicated rats significantly inhibited the increase in serum aspartate aminotransferase (AST) and alanine aminotransferase (ALT) levels, as compared to the group treated with $\mathrm{CCl}_{4}$ only. Histological studies showed less centrolobular necrosis and inflammatory cell in-
\end{abstract}

$\nabla$

The liver is highly involved in metabolic functions and is frequently a target for a great number of toxicants. Many studies have shown that reactive oxygen species are related to the etiology of degenerative diseases, including some hepatopathies [1], [2]. Carbon tetrachloride $\left(\mathrm{CCl}_{4}\right)$ is frequently used as a chemical inducer of experimental liver cirrhosis. This toxic agent elicits liver damage by forming reactive intermediates, such as trichloromethyl free radicals, via cytochrome P450-related functions in the oxidase system [3]. The main causes of $\mathrm{CCl}_{4}$-induced hepatic damage are related to lipid peroxidation, decreased activities of antioxidant enzymes, and generation of free radicals caused by this agent [2].

The antioxidant activity is an important way of providing protection against hepatic damage, and a number of phenol molecules have been shown to possess hepatoprotective properties by improving the liver's antioxidant status [4]. A recent report [5] showed that the extract of

\section{Introduction}

filtrates in the liver of animals treated with $\mathrm{AMB}$ plus $\mathrm{CCl}_{4}$, when compared to the group treated with $\mathrm{CCl}_{4}$ alone. In hepatic tissues, $\mathrm{AMB}$ at both doses inhibited $\mathrm{CCl}_{4}$-induced thiobarbituric acid-reactive substances (TBARS) formation, indicating a blockade of $\mathrm{CCl}_{4}$-induced lipid peroxidation. AMB also reversed the decrement in glutathione contents of hepatic tissues in $\mathrm{CCl}_{4}$-intoxicated rats. Furthermore, it restored catalase activity to normal values, which was significantly increased after $\mathrm{CCl}_{4}$ treatment. Our results indicate that $\mathrm{CCl}_{4}$-induced oxidative damage in hepatic tissues is reversed by AMB treatment. The protective effect of AMB is probably due to the phenolic nature of this glucoside.
Polygonum aviculare L., a species rich in phenols including flavonoids, presents a potent antioxidant effect, probably related to its high content of phenols.

Amburana cearensis belongs to the Fabaceae family and is a medicinal plant used in northeastern Brazil in the treatment of respiratory diseases, including asthma [6]. Phytochemical studies of its trunk bark allowed the isolation of several compounds, such as 3,4-dihydroxybenzoic acid (protocatechuic acid), a mixture of glucosylated $\beta$-sitosterol and stigmasterol, coumarin, four flavonoids (isokaempferide, kaempferol, afrormosin and 4'-methoxyfisetin) and the phenol glucosides, amburosides A and B (AMB, O Fig. 1) [7], [8].

In a previous study [9], we showed that the hydroalcoholic extract, coumarin, and a flavonoid fraction (with isokaempferide as its main constituent) from $A$. cearensis have anti-inflammatory activities and are able to relax the isolated guinea-pig tracheal smooth muscle. Furthermore, we recently [10] demonstrated that the relaxant effect of isokaempferide occurs through several in- 


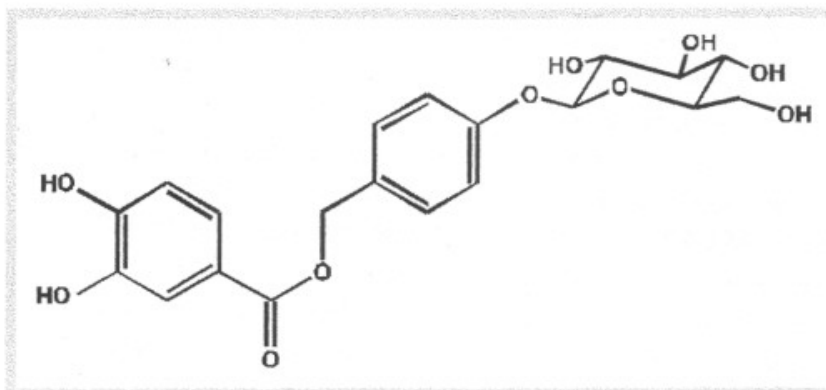

Fig. 1 Chemical structure of amburoside A (AMB) isolated from the trunk bark of Amburana cearensis A. C. Smith.

tracellular actions, having a common pathway such as the opening of $\mathrm{Ca}^{++}$and ATP-sensitive $\mathrm{K}^{+}$channels.

In addition, AMB has been shown to possess antimalarial activity against Plasmodium berghei and no cytotoxicity against tumor cells lines or sea urchin eggs [8], [11]. We also showed [12] that AMB has a significant neuroprotective effect on rat mesencephalic cell cultures exposed to the neurotoxic agent, 6-hydroxydopamine. Thus, the objective of the present work was to expand our previous findings by evaluating whether AMB possesses hepatoprotective activity in the model of $\mathrm{CCl}_{4}$-induced hepatotoxicity in rats. For that, we measured liver enzymes (AST and ALT), thiobarbituric acid reactive substances (TBARS), reduced glutathione levels (GSH) and catalase activity. Besides, liver histological analyses were also carried out.

\section{Materials and Methods}

\section{$\nabla$}

\section{Chemicals}

Carbon tetrachloride, hydrogen peroxide, sulfhydryl reagent [5,5'-dithio-bis (2-nitrobenzoic acid)] (DTNB), 2-thiobarbituric acid, vitamin E and other reagents were purchased from Sigma Chemical company, USA. Diagnostic kits for assaying alanine aminotransferase (ALT) and aspartate aminotransferase (AST) were from Labtest, Brazil. All other drugs were of analytical grade.

\section{Plant material and isolation of amburoside $\mathrm{A}$}

Trunk barks from A. cearensis were collected at the Quixeramobim area, Ceará State, in the Brazilian northeastern region. Voucher specimens (nos. 837 and 847) were deposited at the Prisco Bezerra Herbarium of the Federal University of Ceará (UFC), Fortaleza, Brazil and were authenticated by Dr. Afrânio G. Fernandes, Department of Biology, UFC. The powdered trunk bark ( $3.4 \mathrm{~kg}$ ) was used for the isolation of amburoside A (AMB, $1.02 \mathrm{~g}$ ) ( Fig. 1), according to the method described by Canuto and Silveira [7]. The structure was determined by spectroscopy, including one- and two-dimensional NMR techniques, such as COSY, HMBC and HMQC, physical properties determination, and comparison with data from literature [8].

The purity of AMB (97.3\%) was measured by HPLC analysis, based on the relative area of the target peak at five different wavelengths (220, 254, 328, 387 and $540 \mathrm{~nm})$. HPLC analysis was performed on a Waters 1525 chromatograph, rheodyne injector ( $5 \mu \mathrm{L}$ loop) and photodiode-array detector (Waters-2996 PDA), utilizing a Waters X-Terra RP-18 column $(250 \times 4.6 \mathrm{~mm}$, $5 \mu \mathrm{m}$ ). The mobile phase was prepared from an aqueous solution of $\mathrm{H}_{3} \mathrm{PO}_{4} / \mathrm{Et}_{3} \mathrm{~N}(\mathrm{pH}$ 3.0) and HPLC-grade $\mathrm{MeOH}$, at a gradient mode ( 15 min total run time) varying from 20 to $50 \%$ of the latter, and at a flow rate of $1.0 \mathrm{~mL} / \mathrm{min}$. AMB was dissolved in an aqueous solution containing $4 \%$ Tween 80 .

\section{Animals}

Male Wistar rats $(200 \mathrm{~g})$ from the Animal House of the Federal University of Ceará were maintained at $22 \pm 2^{\circ} \mathrm{C}, 12 \mathrm{~h}$ light $-12 \mathrm{~h}$ dark cycle, and fed with a standard diet (from Purina, Brazil) and tap water ad libitum. Experiments were performed according to the Guide of Care and Use of Laboratory Animals from the European Community. The manuscript protocol used to investigate the pharmacological properties of amburoside $A$, in rats, was approved by our Institutional Ethics Committee.

\section{$\mathrm{CCl}_{4}$-induced liver injury in vivo}

Rats were pretreated with vehicle (aqueous solution of $4 \%$ Tween 80 ), AMB or vitamin E before (30 or $60 \mathrm{~min}$ for i.p. and p.o. administrations, respectively) and $24 \mathrm{~h}$ after carbon tetrachloride ( $50 \% \mathrm{CCl}_{4} /$ olive oil, $0.5 \mathrm{~mL} / \mathrm{kg}$, s. c.) administration. Animals were divided into six groups: (1) negative control (vehicle), (2) $\mathrm{CCl}_{4}$ plus vehicle, (3) AMB (25 mg/kg, i.p.) plus $\mathrm{CCl}_{4}$ treatment, (4) $\mathrm{AMB}\left(50 \mathrm{mg} / \mathrm{kg}\right.$, i.p.) plus $\mathrm{CCl}_{4}$ treatment, (5) $\mathrm{AMB}$ (50 mg/kg, p.o.) plus $\mathrm{CCl}_{4}$ treatment and (6) vitamin $\mathrm{E}(250 \mathrm{mg} /$ $\mathrm{kg}$, p. o.) plus $\mathrm{CCl}_{4}$ treatment. All animals were anesthetized with ether, and the blood was collected from the orbicular plexus in tubes containing heparin $48 \mathrm{~h}$ after $\mathrm{CCl}_{4}$ administration (that is $24 \mathrm{~h}$ after the $2^{\text {nd }}$ drug administration). Animals were sacrificed, and livers were dissected and utilized for biochemical analyses.

\section{Determination of serum transaminases activities}

AST and ALT activities in the rat serum of all groups were measured according to the manufacturer's instructions.

\section{Measurement of malondialdehyde}

The liver was homogenized in $10 \mathrm{vol}$. of ice-cold $1.15 \% \mathrm{KCl}$. The malondialdehyde (MDA) formation in liver homogenates was determined by quantification of thiobarbituric acid reactive substances (TBARS), using the method of Buege and Aust [13] slightly modified. The reaction mixture $(0.5 \mathrm{~mL}$ tissue homogenate, $0.9 \mathrm{~mL}$ of $50 \mathrm{mM}$ phosphate buffer - pH 7.4 and $0.5 \mathrm{~mL}$ of the chemical system generating free radicals $-0.01 \mathrm{mM} \mathrm{FeSO}_{4}$ plus $0.1 \mathrm{mM}$ ascorbic acid) was incubated at $37^{\circ} \mathrm{C}$ for $30 \mathrm{~min}$. The reaction was terminated by adding $1 \mathrm{~mL}$ of $10 \%(\mathrm{w} / \mathrm{v}$ ) trichloroacetic acid (TCA) to the mixture that was centrifuged at $8.000 \times \mathrm{g}$ for $10 \mathrm{~min}$. Supernatants were incubated with $1 \mathrm{~mL}$ of $0.8 \%(\mathrm{w} / \mathrm{v})$ thiobarbituric acid at $100^{\circ} \mathrm{C}$ for $15 \mathrm{~min}$, and after a cooling period TBARS contents were spectrophotometrically determined at $532 \mathrm{~nm}$ using MDA as the standard.

\section{Determination of the reduced glutathione content}

L- $\gamma$-Glutamyl-t-cysteinyl-glycine (GSH) levels were determined by the method of Ellman et al. [14]. Livers were homogenized $(400 \mu \mathrm{L})$ in $1: 10$ volumes of $0.02 \mathrm{M}$ EDTA followed by the addition of $10 \% \mathrm{TCA}$, in order to precipitate the protein contents of homogenates. After centrifugation for $15 \mathrm{~min}$ at $4{ }^{\circ} \mathrm{C}$, the DTNB solution (Ellman's reagent) was added to the supernatants, and the absorbance was measured at $412 \mathrm{~nm}$. Different concentrations of a standard GSH solution $(1 \mathrm{mg} / \mathrm{mL})$ were used to calculate GSH contents, and results were expressed as $\mu \mathrm{g} / \mathrm{mg}$ protein. The protein concentration was measured by the Lowry et al. method [15]. 


\section{Catalase assay}

The method of Aebi [16] was used and consisted in measuring the changes in absorbance of a solution of $10 \mathrm{mM} \mathrm{H}_{2} \mathrm{O}_{2}$ in phosphate buffer, $\mathrm{pH}$ 7.0. The decrease in absorbance per unit time is a measure of catalase activity. The liver homogenate $(20 \mu \mathrm{L})$ was added to the cuvette containing $980 \mu \mathrm{L}$ of the substrate mixture $(0.30 \mathrm{~mL}$ of hydrogen peroxide in $50 \mathrm{~mL}$ of $0.05 \mathrm{M}$ phosphate buffer, $\mathrm{pH}$ 7.0). After $1 \mathrm{~min}$, the initial absorbance was recorded, and the final absorbance was read after $6 \mathrm{~min}$. The reaction was followed at $230 \mathrm{~nm}$, and the results expressed as $\mathrm{mmol} / \mathrm{min} / \mathrm{mg}$ protein. The protein concentration was measured by the Lowry et al. method [15].

\section{Liver histology}

Rats were sacrificed, livers quickly dissected and the pieces immediately fixed in sodium phosphate buffered $10 \%$ formalin $(\mathrm{pH}$ 7.4). Pieces were then placed in $70 \%$ alcohol, followed by 80,90 and $100 \%$ alcohol solutions. Then, pieces were transferred to xylene, embedded in paraffin, and $5 \mu \mathrm{m}$ sections were prepared for staining with heamatoxylin-eosin [17].

\section{Statistical analysis}

Results were expressed as mean \pm SEM. Differences among groups were determined by one-Way analysis of variance (ANOVA), followed by Tukey for multiple comparisons, as a post hoc test. The significance level was set at $\mathrm{p}<0.05$.

\section{Results \\ $\checkmark$}

- Table 1 shows that, after $\mathrm{CCl}_{4}$ administration, both serum transaminases were markedly increased by 2.6 - and 2.5 -fold, respectively $\left(\mathrm{CCl}_{4}\right.$, ALT: $89.8 \pm 5.5$; AST: $\left.137.9 \pm 6.1 \mathrm{U} / \mathrm{L}\right)$, as compared to the control (ALT: $33.5 \pm 3.5 \mathrm{U} / \mathrm{L}$; AST: $54.5 \pm 2.5 \mathrm{U} / \mathrm{L}$ ). AMB treatment ( 25 and $50 \mathrm{mg} / \mathrm{kg}$, i.p.), in the presence of $\mathrm{CCl}_{4}$, significantly reduced the activities of ALT by $28 \%$ (AMB25 + $\left.\mathrm{CCl}_{4}: 53.3 \pm 4.9 ; \mathrm{AMB} 50+\mathrm{CCl}_{4}: 36.3 \pm 4.8 \mathrm{U} / \mathrm{L}\right)$ and those of AST by $59 \%\left(\mathrm{AMB} 25+\mathrm{CCl}_{4}: 103.8 \pm 7.9 ; \mathrm{AMB} 50+\mathrm{CCl}_{4}: 80.9 \pm 6.7 \mathrm{U} /\right.$ $\mathrm{L}$ ), if compared to the $\mathrm{CCl}_{4}$ group. The oral administration of AMB $(50 \mathrm{mg} / \mathrm{kg})$ or vitamin E $(250 \mathrm{mg} / \mathrm{kg})$ caused inhibitions of $40 \%$ in both enzymes.

- Fig. 2 shows the effect of AMB on TBARS formation (expressed as $\mathrm{mmol} \mathrm{MDA} / \mathrm{mg}$ protein), as a parameter of liver peroxidation. After $\mathrm{CCl}_{4}$ administration, TBARS contents in the liver homogenate were increased by around 2.4-fold in $\mathrm{CCl}_{4}$-intoxicated rats $(10.2 \pm 0.5)$, as compared to controls $(4.2 \pm 0.2)$. The intraperitoneal or oral administration of AMB, at the doses of $25(6.4 \pm 1.0)$ and $50 \mathrm{mg} / \mathrm{kg}(7.8 \pm 0.3)$, respectively, reduced significantly the formation of TBARS in liver homogenates in $\mathrm{CCl}_{4}$-intoxicated rats. In addition, AMB $(4.8 \pm 0.5)$ at the dose of $50 \mathrm{mg} / \mathrm{kg}$, i. p. markedly reduced TBARS formation, whose values returned to normal levels. Vitạmin $\mathrm{E}$ also protected against $\mathrm{CCl}_{4}$-hepatotoxicity, and values were close to those of controls $(5.6 \pm 0.7)$.

- Fig. 3 shows changes in reduced glutathione levels (GSH) in liver tissues of $\mathrm{CCl}_{4}$-intoxicated rats. Hepatic GSH levels ( $\mu \mathrm{g} / \mathrm{mg}$ protein) significantly decreased from $10.4 \pm 0.6$ in the control group (without $\mathrm{CCl}_{4}$ treatment) to $5.7 \pm 0.2$ in the $\mathrm{CCl}_{4}$-treated group. The decreased GSH levels observed after $\mathrm{CCl}_{4}$ treatment were almost completely restored to normal values by intraperitoneal $(25$ and $50 \mathrm{mg} / \mathrm{kg}$ ) or oral $(50 \mathrm{mg} / \mathrm{kg})$ administrations of AMB, respectively (i.p.: $\mathrm{AMB} 25+\mathrm{CCl}_{4}: 8.2 \pm 0.5 ; \mathrm{AMB} 50+\mathrm{CCl}_{4}$ : $8.7 \pm 0.4$; p.o.: AMB50 $\left.+\mathrm{CCl}_{4}: 9.6 \pm 0.4\right)$. The effect of AMB
( $50 \mathrm{mg} / \mathrm{kg}$, p.o.) was comparable to that of the standard vitamin $\mathrm{E}(10.6 \pm 0.8)$.

The liver catalase activity ( $\mathrm{nmol} / \mathrm{min} / \mathrm{mg}$ protein) was $76.7 \pm 8.25$ in the control group ( $\mathbf{O}$ Fig. 4 ), and increased to $156.5 \pm 14.8$ in $\mathrm{CCl}_{4}$-intoxicated rats ( $\mathrm{CCl}_{4}$ group). $\mathrm{AMB}$ ( 25 and $50 \mathrm{mg} / \mathrm{kg}$, i.p. ) in the presence of $\mathrm{CCl}_{4}$ significantly $(\mathrm{p}<0.001)$ reduced the enzyme activity (AMB50 $+\mathrm{CCl}_{4}: 75.0 \pm 10.2$ ), indicating a hepatoprotective effect. No significant effect was seen with $A M B$, at the lower dose. In addition, both $A M B(50 \mathrm{mg} / \mathrm{kg}$, i.p.) and vitamin $\mathrm{E}$ restored the enzymatic activity to normal levels. The oral administration of AMB, at the dose of $50 \mathrm{mg} / \mathrm{kg}$, also partially restored catalase activity, although the effect was less pronounced than that of $A M B$ at $50 \mathrm{mg} / \mathrm{kg}$, i.p.

Liver sections from control, $\mathrm{CCl}_{4}$ - treated, $\mathrm{AMB}+\mathrm{CCl}_{4}$ (25 and $50 \mathrm{mg} / \mathrm{kg})$ and vitamin $\mathrm{E}(250 \mathrm{mg} / \mathrm{kg})$ groups are presented in - Fig. 5. The results show that $\mathrm{CCl}_{4}$ produced considerable necrosis and degeneration of liver cells around the central lobule,

Table 1 Effects of amburoside A (AMB) from Amburana cearensis on serum AST and ALT levels in $\mathrm{CCl}_{4}$-intoxicated rats

\begin{tabular}{|c|c|c|}
\hline Group & AST (U/L) & ALT (U/L) \\
\hline Control & $54.5 \pm 2.5$ & $33.5 \pm 3.5$ \\
\hline $\mathrm{CCl}_{4}$ & $137.9 \pm 6.1 \mathbf{a}$ & $89.8 \pm 5.5 a$ \\
\hline AMB $25 \mathrm{mg} / \mathrm{kg}, i . p .+\mathrm{CCl}_{4}$ & $103.8 \pm 7.9 b$ & $53.3 \pm 4.9 b$ \\
\hline AMB $50 \mathrm{mg} / \mathrm{kg}$, i.p. $+\mathrm{CCl}_{4}$ & $80.9 \pm 6.7 b$ & $36.3 \pm 4.8 \mathbf{b}$ \\
\hline AMB $50 \mathrm{mg} / \mathrm{kg}$, p.o. $+\mathrm{CCl}_{4}$ & $77.5 \pm 6.0 b$ & $49.2 \pm 7.3 \mathbf{b}$ \\
\hline $\begin{array}{l}\text { Vitamin E } 250 \mathrm{mg} / \mathrm{kg} \text {, } \\
\text { p.o. }+\mathrm{CCl}_{4}\end{array}$ & $82.3 \pm 7.4 b$ & $46.0 \pm 5.0 b$ \\
\hline \multicolumn{3}{|c|}{$\begin{array}{l}\mathrm{CCl}_{4} \text {-intoxicated rats were treated with vehicle or } \mathrm{AMB}(25 \text { and } 50 \mathrm{mg} / \mathrm{kg}) \text {, } \\
30 \text { min before and } 24 \text { after } \mathrm{CCl}_{4} \text { administration. The } \mathrm{AST} \text { and } \mathrm{ALT} \text { levels were } \\
\text { measured in heparinized plasma obtained } 48 \mathrm{~h} \text { after } \mathrm{CCl} 4 \text { administration. } \\
\text { Values are expressed as means } \pm \text { S.E.M. a vs control (without } \mathrm{CCl}_{4} \text { treatment); } \\
\text { b vs } \mathrm{CCl}_{4}(p<0,05 \text {, ANOVA and Tukey, as the post hoc test). }\end{array}$} \\
\hline
\end{tabular}

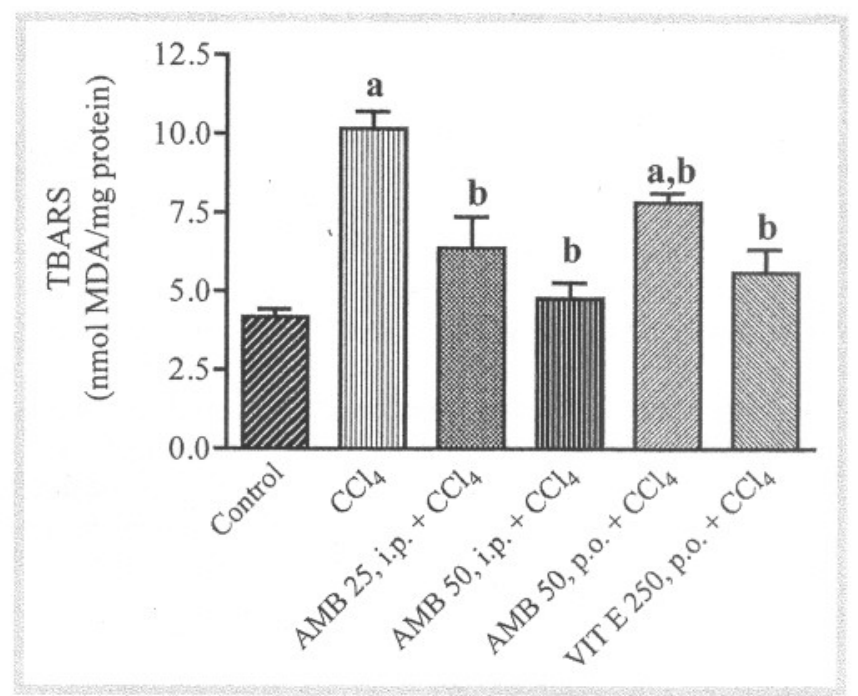

Fig. 2 Effects of $A M B$ on hepatic lipid peroxidation in $\mathrm{CCl}_{4}$-intoxicated rats. Animals were treated with AMB ( 25 and $50 \mathrm{mg} / \mathrm{kg}$, i. p.; $50 \mathrm{mg} / \mathrm{kg}$, p. o.) or vitamin $\mathrm{E}\left(250 \mathrm{mg} / \mathrm{kg}\right.$, p. o.), before and $24 \mathrm{~h}$ after $\mathrm{CCl}_{4}$ administration. They were sacrificed $48 \mathrm{~h}$ after $\mathrm{CCl}_{4}$ (that is, $24 \mathrm{~h}$ after the $2^{\text {nd }}$ drug administration). The content of malondialdehyde (MDA) formation in the liver homogenate was determined by the quantification of thiobarbituric acid reactive substances (TBARS). Values are expressed as means \pm S.E.M. a vs. control group (without $\mathrm{CCl}_{4}$ treatment); b vs. $\mathrm{CCl}_{4}$-treated group ( $\mathrm{p}<$ 0.05 , ANOVA and Tukey as the post hoc test). 


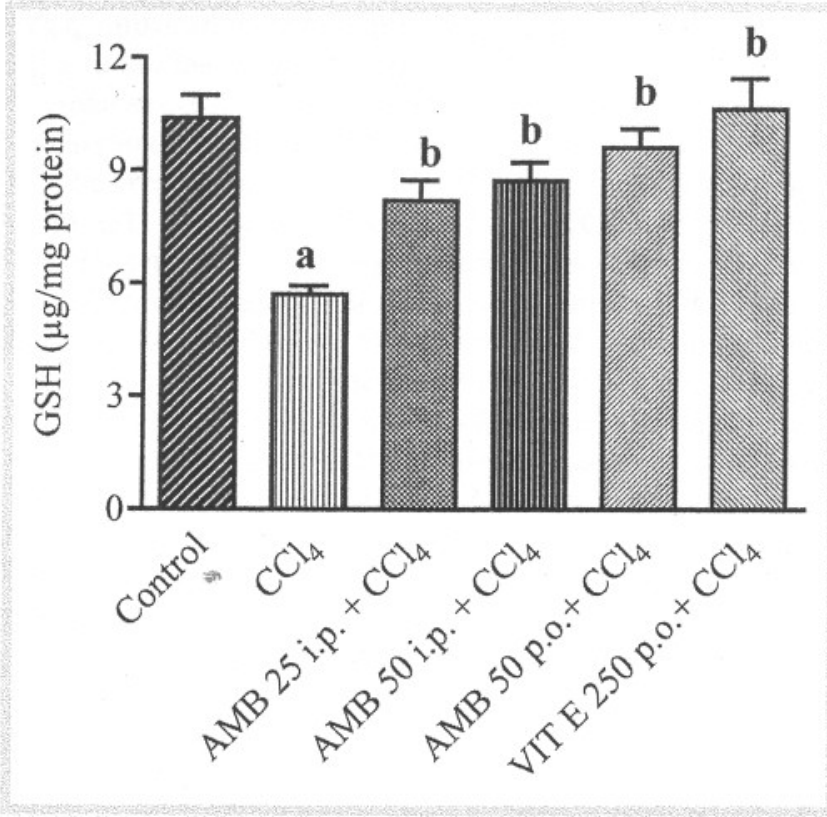

Fig. 3 Effects of AMB on hepatic reduced glutathione (GSH) levels in $\mathrm{CCl}_{4}$-intoxicated rats. Animals were treated with $\mathrm{AMB}(25$ and $50 \mathrm{mg} / \mathrm{kg}$, i. p.; $50 \mathrm{mg} / \mathrm{kg}$, p. o.) or vitamin $\mathrm{E}(250 \mathrm{mg} / \mathrm{kg}$, p. o.), before and 24 after $\mathrm{CCl}_{4}$ administration. They were sacrificed $48 \mathrm{~h}$ after $\mathrm{CCl}_{4}$ (that is, $24 \mathrm{~h}$ after the $2^{\text {nd }}$ drug administration). GSH contents were determined by the DTNB conjugation method. Values are expressed as means \pm S.E.M. a vs. control group (without $\mathrm{CCl}_{4}$ treatment); b vs. $\mathrm{CCl}_{4}$ group ( $\mathrm{p}<0.05$, ANOVA and Tukey as the post hoc test).

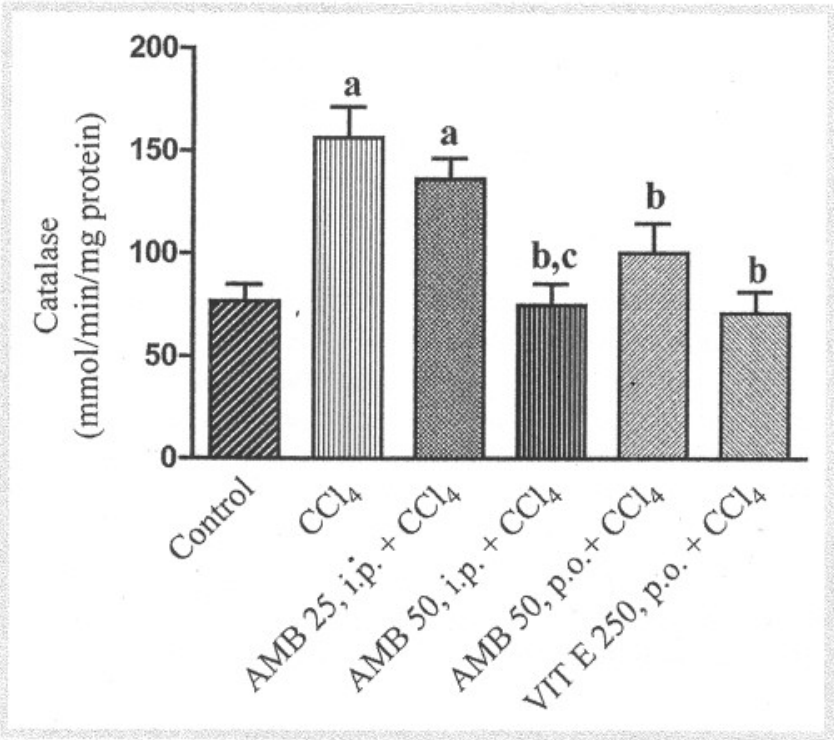

Fig. 4 Effects of $\mathrm{AMB}$ on hepatic catalase activity in $\mathrm{CCl}_{4}$-intoxicated rats. Animals were treated with $\mathrm{AMB}$ ( 25 and $50 \mathrm{mg} / \mathrm{kg}$, i. p.; $50 \mathrm{mg} / \mathrm{kg}$, p.o.) or vitamin $\mathrm{E}(250 \mathrm{mg} / \mathrm{kg}, p$.o. $)$, before and $24 \mathrm{~h}$ after $\mathrm{CCl}_{4}$ administration. They were sacrificed $48 \mathrm{~h}$ after $\mathrm{CCl}_{4}$ (that is, $24 \mathrm{~h}$ after the $2^{\text {nd }}$ drug administration). Catalase activity was determined according to Aebi [16]. Values are expressed as means \pm S.E.M. a vs. control group (without $\mathrm{CCl}_{4}$ treatment); b vs. $\mathrm{CCl}_{4}$ group; $c$ vs. AMB 25 group ( $p<0.05$, ANOVA and Tukey as the post hoc test).

as well as significant increases in serum transaminases activities (- Table 1), as compared to controls. Infiltration of inflammatory cells was also found in $\mathrm{CCl}_{4}$-intoxicated rats. On the other hand, the damage was significantly small in rats treated with
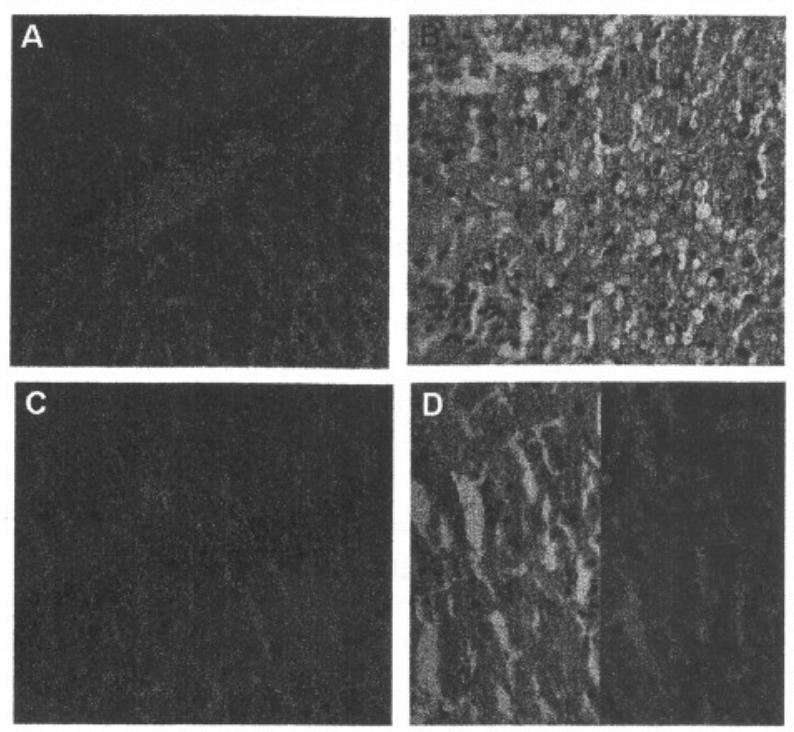

Fig. 5 Effects of amburoside A (AMB) on hepatic morphological analysis, after $\mathrm{CCl}_{4}$ administration, in rats. Animals were treated with AMB (25 and $50 \mathrm{mg} / \mathrm{kg}$, i. p.; $50 \mathrm{mg} / \mathrm{kg}$, p.o.) or vitamin $\mathrm{E}(250 \mathrm{mg} / \mathrm{kg}$, p. o. $)$ before and $24 \mathrm{~h}$ after $\mathrm{CCl}_{4}$ administration. They were sacrificed $48 \mathrm{~h}$ after $\mathrm{CCl}_{4}$ (that is, $24 \mathrm{~h}$ after the $2^{\text {nd }}$ drug administration). Liver sections were stained with hematoxylin-eosin by standard techniques for photomicrographies $(\times 40)$. Figure (A) is from a normal rat without $\mathrm{CCl}_{4}$ treatment; Figure (B) is from a rat treated with $\mathrm{CCl}_{4}$ only. Representative Figures (C) and (D) are from rats treated with vitamin $\mathrm{E}(250 \mathrm{mg} / \mathrm{kg}$, p. o. $)$ and $\mathrm{AMB}(50 \mathrm{mg} / \mathrm{kg}$, p.o), respectively.

$\mathrm{AMB}$, prior and after $\mathrm{CCl}_{4}$ administration. Furthermore, vitamin $\mathrm{E}$ also markedly reduced the alterations in acute $\mathrm{CCl}_{4}$-mediated liver damage.

\section{Discussion \\ $\nabla$}

In the present work, AMB (4-(O- $\beta$-D-glycopyranosylbenzyl protocatechoate), isolated from Amburana cearensis, administered by oral or intraperitoneal routes exhibited hepatoprotective activity against $\mathrm{CCl}_{4}$-induced hepatotoxicity in rats. $\mathrm{AMB}$ is a phenol glucoside and one of the bioactive components present in this Brazilian medicinal plant, popularly used for the treatment of respiratory tract affections.

Polyphenols have been shown to be more effective antioxidants in vitro than tocopherols and ascorbate. Antioxidant properties of polyphenols arise from their high reactivity as hydrogen or electron donors, from the ability of polyphenol-derived radicals to stabilize unpaired electrons and to chelate transition metal ions. Another mechanism underlying the antioxidative properties of phenols is the ability of flavonoids to alter peroxidation kinetics by modifying the lipid packing order and decreasing membranes fluidity [18]. Recently, Panda and Kar [19] demonstrated that apigenin (4',5,7-trihydroxyflavone) has the potential to regulate diabetes mellitus, as well as this disease-induced thyroid dysfunction and lipid peroxidation in mice.

In the liver, the first cells to be damaged by $\mathrm{CCl}_{4}$ through the $\mathrm{CCl}_{4}$-derived and highly reactive free radical metabolite trichloromethyl $\mathrm{CCl}_{3}$ are those in the centrilobular region where enzyme activities are the greatest [20]. Kupffer cells, the major component of the hepatic sinusoid, and macrophages sensitized to 
$\mathrm{CCl}_{4}$ intoxication release pro-inflammatory cytokines, such as the tumor necrosis factor alpha (TNF-alpha). The expression of cytokines occurs through NF- $\kappa \mathrm{B}$ activation during hepatocellular injury in the acute $\mathrm{CCl}_{4}$-mediated liver damage [21].

In the present study, activities of the hepatic transaminases (ALT and AST) were markedly elevated after $\mathrm{CCl}_{4}$ administration in the rat serum, and AMB significantly reduced these effects. The assessment of hepatic transaminases is the easiest method for estimating liver damage. Necrosis or membrane damage release these enzymes into circulation. AST is present in the liver, heart, muscle, kidney and brain whereas ALT is more specific to the liver. Our results suggest that AMB has a hepatoprotective activity in $\mathrm{CCl}_{4}$-intoxicated rats, and this $\mathrm{AMB}$ action was corroborated by histological data. Thus, $\mathrm{CCl}_{4}$-treatment caused massive histopathological changes such as necrosis, congested vessels, multifocal areas of fatty changes, nuclear disintegration, sinusoidal dilation, and Kupffer cells hyperplasia. Prevention of these events can be considered as a hepatoprotective activity.

The lipid peroxidative degradation of biomembranes is one of the main causes of $\mathrm{CCl}_{4}$ toxicity. Lipid peroxidation also leads to a wide range of cytotoxic products (such as malondialdehyde and 4-hydroxynonenal), inhibiting protein synthesis and the activities of certain enzymes [22]. Our results, using the model of $\mathrm{CCl}_{4}$-induced hepatotoxicity in rats, demonstrated that $\mathrm{AMB}$ caused significant decreases in TBARS levels when compared to the group treated with $\mathrm{CCl}_{4}$ only. These results indicate that $\mathrm{AMB}$ protects liver tissues against lipid peroxidation.

Biological systems defend themselves against the damaging effects of reactive oxygen species (ROS) by several means, including free radical scavengers and chain reaction terminators, enzymes such as superoxide dismutase, catalase, and glutathione peroxidase (GPx) systems [23]. The administration of $\mathrm{CCl}_{4}$ induced a significant increase in the catalase activity when compared to the control group. A significant reversal of this change towards normal values was observed after the administration of $\mathrm{AMB}$ or vitamin E used as standard when compared to the $\mathrm{CCl}_{4}$ treated group alone.

Rohrdanz et al. [24] reported that catalase activity and mRNA expression were induced in hepatocytes after their exposure to hydrogen peroxide. In addition, Szymonik-Lesiuk ęt al. [25] showed that catalase activity in the liver was significantly increased at 24 and $72 \mathrm{~h}$ after $\mathrm{CCl}_{4}$ intoxication. Thus, increased catalase activity in $\mathrm{CCl}_{4}$-intoxicated rats, demonstrated in the present study, may be explained by the increase in the enzyme expression caused by the accumulation of ROS in the liver as observed by others [26]. We can then assume that the reduction of catalase activity by AMB may be a consequence of its antioxidant effect.

Glutathione is a ubiquitous, non-essential sulfhydryl amino acid and an antioxidant thiol that plays a crucial role in maintaining redox equilibrium and establishing mechanisms of cellular defense seen during oxidative stress [27]. In our study, $\mathrm{CCl}_{4}$ administration caused a significant reduction of GSH in the liver that was almost completely reversed by AMB. The depletion of GSH in the $\mathrm{CCl}_{4}$ group may be explained by the increased utilization of GSH required for the removal of ROS and lipid damaged products. Otherwise, decreases of ROS production in the AMB pretreated groups may reduce the consumption of GSH for ROS scavenger.

Galato et al. [28] investigated the antioxidant capacity of phenols and related compounds and observed that the greater the number of hydroxyls linked to the aromatic ring, the greater is the anti- oxidant activity of the compounds. Thus, it is possible that hydroxyl groups, present in the AMB molecule aromatic ring, contribute to the drug antioxidant activity.

Our data suggest that the hepatoprotective activity of AMB in $\mathrm{CCl}_{4}$-induced liver injury is related to its antioxidative property and its ability to scavenge free radicals involved with $\mathrm{CCl}_{4}$-mediated lipid peroxidation. In a previous study [12], we showed an antioxidant activity of AMB on rat mesencephalic cell cultures after their exposure to 6-OHDA. Inhibition of cytochrome P450 (CYP2E1) was also reported to account for the hepatoprotective actions reported for some compounds [29]. However, determining whether $\mathrm{AMB}$ is a cytochrome $\mathrm{P} 450$ inhibitor still requires further investigation.

In the present study, we showed that $\mathrm{AMB}$, especially at the higher dose, possesses hepatoprotective properties in the $\mathrm{CCl}_{4}$ induced liver toxicity model in rats. These effects may be due, at least in part, to a reduction in hepatic peroxidative activities, as well as by a significant restoration to normal levels of the catalase activity and $\mathrm{GSH}$ contents observed in $\mathrm{CCl}_{4}$-intoxicated rats after AMB treatment. These effects are probably related to the presence of hydroxyl groups in the AMB phenol structure, as previously demonstrated to occur with other natural phenols [5]. Finally, the observed hepatoprotective action of AMB from $A$. cearensis may be justified, at least in part, by its antioxidant property [12]. Other plant glucosides are also known to decrease ALT, AST, lipid peroxidation, and nitrite levels in rat serum in the $\mathrm{CCl}_{4}$-induced hepatotoxicity model [30].

\section{Acknowledgments}

$\nabla$

This work was supported by grants from Conselho Nacional de Desenvolvimento Científico e Tecnológico (CNPq, Brazil), Financiadora de Estudos e Projetos (FINEP, Brazil), and Fundação Cearense de Amparo à Pesquisa (FUNCAP, Brazil). The authors thank Prof. M.O.L. Viana for the orthographic revision of the manuscript and Ms. M.V.R. Bastos for technical assistance.

\section{References}

1 Meyer SA, Kulkarni AP. Hepatotoxicity. In: Hodgson E, Smart RC, editors. Introduction to biochemical toxicology, 3 rd edition. New York: John Wiley \& Sons; 2001

2 Poli G. Liver damage due to free radicals. Br Med Bull 1993; 49: 60420

3 Recknagel RO, Glende EA Jr, Dolak JA, Waller RL. Mechanisms of carbon tetrachloride toxicity. Pharmacol Ther 1989; 43: 139-54

4 Handa SS, Sharma A, Chakraborti KK. Natural products and plants as liver protecting drugs. Fitoterapia 1986; 57: 307-45

$5 \mathrm{Hsu} C$-Y. Antioxidant activity of extract from Polygonum aviculare L. Biol Res 2006; 39: 281-8

6 Braga R. Plantas do Nordeste especialmente do Ceará, 3 rd Edition Fortaleza: Imprensa Oficial; 1976: 219

7 Canuto KM, Silveira ER. Constituintes químicos da casca do caule de Amburana cearensis A. C. Smith. Quim Nova 2006; 29: 1241 -3

8 Bravo B, Sauvain M. Bioactive phenolic glycosides from Amburana cearensis. Phytochemistry 1999; 50: 71-4

9 Leal LKAM, Nechio M, Silveira ER, Canuto KM, Fontenele RA, Viana GSB. Anti-inflammatory and smooth muscle relaxant activities of the hydroalcoholic extract and chemical constituents from Amburana cearensis A. C. Smith. Phytother Res 2003; 17: 335-40

10 Leal LKAM, Costa MF, Pitombeira M, Silveira ER, Canuto KM, Viana GS. Mechanisms underlying the relaxation induced by isokaempferide from Amburana cearensis in the guinea-pig isolated trachea. Life Sci 2006; 79: $98-104$

11 Costa-Lotufo LV, Jimenez PC, Wilke DV, Leal LKAM, Silveira ER, Viana GSB. Antiproliferative effects of several compounds isolated from Amburana cearensis A.C.Smith. Z Naturforsch [C] 2003; 58: 675-80 
12 Leal LKAM, Moraes MO, Pessoa C, Silveira ER, Canuto KM, Viana GSB. Amburoside A, a glucoside from Amburana cearensis, protects mesencephalic cells against 6-hydroxydopamine-induced neurotoxicity. Neurosci Lett 2005; 388: 86-90

13 Buege JA, Aust SD. Microsomal lipid peroxidation. Methods Enzymol 1978; $52: 302-10$

14 Ellman GL. Tissue sulfhydryl group. Arch Biochem Biophys 1959; 82: 70-7

15 Lowry $\mathrm{OH}$, Rosebrough AL, Randall RJ. Protein measurement with folin phenol reagent. Biol Chem 1951; 193: 265-71

16 Aebi H. Catalase in vitro. Methods Enzymol 1974; 2: 673-8

$17 \mathrm{Ha} \mathrm{JB}$, Lee JY. The effect of chondroitin sulfate against $\mathrm{CCl}_{4}$-induced hepatotoxicity. Biol Pharm Bull 2003; 26: 622-6

18 Arora A, Byrem TM, Nair MG, Strasburg GM. Modulation of liposomal membrane fluidity by flavonoids and isoflavonoids. Arch Biochem Biophys 2000; $373: 102-9$

19 Panda S, Kar A. Apigenin (4',5,7-trihydroxyflavone) regulates hyperglycaemia, thyroid dysfunction and lipid peroxidation in alloxan-induced diabetic mice. J Pharm Pharmacol 2007; 59: 543-8

20 Cabre M, Comps J, Paternain JL, Ferre N, Joven J. Time course of changes in hepatic lipid peroxidation and glutothione metabolism in rats with carbon tetrachloride-induced cirrhosis. Clin Exp Pharmacol Physiol 2000; $27: 694-9$

21 Edwards MJ, Keller BJ, Kauffman FC, Thurman RG. The involvement of Kupffer cells in carbon tetrachloride toxicity. Toxicol Appl Pharmacol 1993; 119: $275-9$
22 Shigeki A, Masayuki I. Physiological role of sinusoidal endothelial cells and Kupffer cells and their implication in pathogenesis of liver injury. J Hepatobiliary Pancreat Surg 1999; 7: 40-8

23 Proctor PH, McGinness JE. The function of melanin. Arch Dermatol 1986; 122: $507-8$

24 Rohrdanz E, Kahl R. Alterations of antioxidant enzyme expression in response to hydrogen peroxide. Free Radic Biol Med 1998; 24: 27 - 38

25 Szymonik-Lesiuk S, Czechowska G, Stryjecka-Zimmer M, Slomka M, Madro A, Celinski $K$ et al. Catalase, superoxide dismutase, and glutathione peroxidase activities in various rat tissues after carbon tetrachloride intoxication. J Hepatobiliary Pancreat Surg 2003; 10: 309-15

26 Shull S, Heintz NH, Periasamy M, Mamokor M, Jansen YMW, Marsh IP et al. Differential regulation of antioxidant enzymes in response to oxidants. J Biol Chem 1991; 266: 24398-403

27 Rahman I, Biswas SK, Jimenez LA, Torres M, Forman HJ. Glutathione, stress responses, and redox signaling in lung inflammation. ARS 2005; 7: $42-59$

28 Galato D, Ckless K, Susin MF, Giacomelli C, Ribeiro-do-Valle RM, Spin A. Antioxidant capacity of phenolic and related compounds: correlation among electrochemical, visible spectroscopy methods and structureantioxidant activity. Redox Rep 2001; 6: 243-50

29 Zhao ZS, O'Brien PJ. The prevention of $\mathrm{CCl}_{4}$-induced liver necrosis in mice by naturally occurring methylenedioxybenzenes. Toxicol Appl Pharmacol 1996; 140: 411-21

30 Mohamed MA, Marzouk MS, Moharram FA, El-Sayed MM, Baiuomy AR. Phytochemical constituents and hepatoprotective activity of Viburnum tinus. Phytochemistry 2005; 66: 2780-6 